\title{
Relationship between Plasma Osmolality and Plasma Concentration of Antidiuretic Hormone in Normal Subjects, Patients with Chronic Renal Diseases, and Patients with Central Diabetes Insipidus
}

\author{
Tokinisa Kimura,* Kuniaki Matsui,* Tatsuo Sato,* \\ Kaoru Yoshinaga* and Takeshi Hoshi $\dagger$ \\ Department of Internal Medicine* and Department of Physio- \\ logy, $\dagger$ Tohoku University School of Medicine, Sendai
}

Kmmura, T., Matsui, K., Sato, T., Yoshinaga, K. and Hoshi, T. Relationship between Plasmx Osmolality and Plasma Concentration of Antidiuretic Hormone in Normal Subjects, Patients with Chronic Renal Diseases, and Patients with Central Diabetes Insipidus. Tohoku J. exp. Med., 1974, 113 (1), 77-88 —_Using improved bioassay techniques, plasma concentration of the antidiuretic hormone $(\mathrm{ADH})$ was determined in thirteen normal subjects, seven patients with chronic renal diseases, and ten patients with central diabetes insipidus. Three different experimental conditions were examined, at two hr after lunch or supper at rest (standard conditions); after overnight restriction of water intake (dehydrated conditions) and after loading excess water (overhydrated conditions). Osmolality of plasma and urine was also determined. The mean values for $\mathrm{ADH}$ concentration in plasma of normal subjects under the standard, dehydrated and over-hydrated conditions were $3.2 \pm 0.5,4.0 \pm 0.8$, and $0.8 \pm 0.2 \mu \mathrm{U} / \mathrm{ml}$, respectively. Collected data obtained from normal subjects revealed that plasma $\mathrm{ADH}$ concentration sharply rose when plasma osmolality exceeded $270 \mathrm{mOsm} / \mathrm{kg}$, but apparent plasma threshold osmolality which caused $\mathrm{U} / \mathrm{P}$ osmolar ratio of more than unity was around $275-285 \mathrm{mOsm} / \mathrm{kg}$. When compared the ADH levels between standard and dehydrated conditions for individual subjects there were significant increases after the dehydration despite unchanged plasma osmolality, suggesting that some factor or factors other than plasma osmolality may modify the relationship beteen plasma ADH concentration and osmolality. In patients with chronic renal diseases, plasma ADH concentration for the standard and dehydrated states were $3.3 \pm 0.9$ and 4.9 $\pm 1.3 \mu \mathrm{U} / \mathrm{ml}$, respectively. These patients responded to dehydration with an increase in $\mathrm{ADH}$ concentration but with much less increase in $U / P$ osmolar ratio. The findings are in accord with the pathophysiological conditions of these patients with impaired renal concentrating capacity without impaired ADH releasing mechanism. In patients with central diabetes insipidus, plasma ADH concentration under the standard and dehydrated states (after $3 \%$ decrease in body weight) were $0.4 \pm 0.1$ and $0.9 \pm 0.2 \mu \mathrm{U} / \mathrm{ml}$, respectively. These patients responded to the dehydration test with a remarkable increase in plasma osmolality $(288.6 \pm$ 5.3 to $300 \pm 7.3 \mathrm{mOsm} / \mathrm{kg}$ ) without significant increase in plasma ADH concentration. - plasma ADH; plasma osmolality; urinary osmolality; chronic renal diseases; diabetes inspidus

Received for publication, March 23, 1974.

Address reprint requests to: Dr. Tokihisa Kimura, Department of Internal Medicine, Tohoku University Hospital, Sendai, Japan, 980. 
Although the release of $\mathrm{ADH}$ from the neurohypophysis is influenced by many factors, it is generally accepted that the principal stimulant is the osmolality of plasma or extracellular fluid. It is also believed that there is a threshold osmolality of plasma for the ADH release. Several authors have attempted to estimate this threshold osmolality in animals (O'Conner 1962) and in man (Aubry et al. 1965; Moses et al. 1967). However, the methods employed in their studies are mostly indirect, and there are few reports dealing with direct relationship between plasma osmolality and plasma concentration of $\mathrm{ADH}$.

In the present study, plasma concentration of $\mathrm{ADH}$, plasma osmolality and urine osmolality were measured simultaneously in normal subjects, patients with chronic renal diseases, and patients with central diabetes insipidus. Analyses were made on both the relationships between plasma osmolality and plasma concentration of $\mathrm{ADH}$ and between plasma $\mathrm{ADH}$ level and urine osmolality in each group of subjects.

\section{Materials and Methods}

The subjects investigated were 13 normal volunteers and 7 patients with ehronic renal diseases including chronic glomerulonephritis (5 patients), polycystic kidney (one patient) and nephrocalcinosis (one patient) and 10 patients with central diabetes insipidus. Clinical data of patients with chronic renal disease pertaining to their renal functions are summarized in Table 1.

TABLE 1. Clinical data of patients with chronic renal disease

\begin{tabular}{|c|c|c|c|c|c|c|c|c|}
\hline Case & Sex & Age & Diagnosis & $\begin{array}{c}\text { Blood } \\
\text { pressure } \\
\text { (mmHg) }\end{array}$ & $\begin{array}{c}\text { BUN } \\
(\mathrm{mg} / 100 \mathrm{ml})\end{array}$ & $\begin{array}{c}\text { PSP } \\
(15 \mathrm{~min}) \\
(\%)\end{array}$ & $\begin{array}{c}\text { GFR } \\
(\mathrm{ml} / \mathrm{min})\end{array}$ & $\underset{(\mathrm{ml} / \mathrm{min})}{\mathrm{RPF}}$ \\
\hline O.N. & Male & 38 & Chronic Gl.N. & $120-80$ & 39 & 8.9 & 35.0 & 254 \\
\hline S.T. & Male & 19 & Chronic Gl.N. & $150-80$ & 65 & 3.0 & 7.8 & - \\
\hline T.K. & Male & 37 & Chronic Gl.N. & $150-100$ & 22 & 19.5 & 79.3 & 266 \\
\hline Т.J. & Male & 48 & Chronic Gl.N. & $250-150$ & 39 & 8.0 & 31.4 & 93 \\
\hline H.A. & Male & 22 & Chronic Gl.N. & $150-90$ & 33 & - & 55.0 & 216 \\
\hline A.E. & Male & 24 & Cystic kidney & $170-90$ & 24 & 13. 7 & 74.7 & - \\
\hline T.H. & Male & 19 & Nephrocalcinosis & $145-75$ & 15 & 16 & 67 & 321 \\
\hline
\end{tabular}

States of hydration

Standard conditions: After the lunch or supper, all subjects were requested to be relaxed in bed for $2 \mathrm{hr}$. The conditions at the end of this resting period are referred to as the standard conditions in this paper. At this time, $20 \mathrm{ml}$ of blood were collected.

Overhydrated conditions: Water loading was carried out after $2 \mathrm{hr}$ resting period following lunch. $20 \mathrm{ml}$ of water per $\mathrm{kg}$ body weight were given orally within about 30 min. After 90 to $120 \mathrm{~min}$, when urine flow rate reached above $7 \mathrm{ml} / \mathrm{min}$, the second blood. and urine samples were collected.

Dehydrated conditions: After the collection of blood and urine under the standard conditions after supper, body weight and hematocrit of each subject were measured. Thereafter, until $9.30 \mathrm{a} . \mathrm{m}$. in the next morning, the subjects were given neither food nor water. At the end of period of water deprivation for $14 \mathrm{hr}$, blood and urine samples were collected, and again body weight was measured. In patients with central diabetes insipidus, the test was slightly modified as follows. After breakfast, they were requested to be at rest in bed for $2 \mathrm{hr}$ but allowed free access to water. After this resting period, the first 
specimen of venous blood was taken. Water deprivation test was then started and continued until the subjects had lost $2-3 \%$ of body weight, or until the thirst had become unbearable to them. The second specimens of blood and urine were obtained at the end of the test.

\section{Assay of plasma ADH}

$20 \mathrm{ml}$ of blood was withdrawn from the antecubital vein into a heparinized plastic syringe. The blood was transferred immediately into a plastic centrifuge tube to centrifuge at $3,000 \mathrm{rpm}$ for $15 \mathrm{~min}$ at $4^{\circ} \mathrm{C}$. Separated plasma was kept in a deep freezer at $-25^{\circ} \mathrm{C}$ until the commencement of extraction procedures.

Plasma ADH was determined by a modified method similar to those employed by Yoshida et al. (1963), Claybaugh and Share (1972) and Moran et al. (1964). Some minor modifications were made to improve the recovery rate of $\mathrm{ADH}$. Briefly, $10 \mathrm{ml}$ of plasma was deproteinized with trichloroacetic acid and the supernatant was washed three times with equal volume of ethylether. The $\mathrm{pH}$ of aqueous phase was then adjusted to 4.5 with diluted ammonia, and the sample was applied onto a CG-50 rein column, $\mathrm{H}^{+}$form, of $1 \mathrm{~cm}$ in diameter and $1 \mathrm{~cm}$ in height. The flow rate was kept at about $1 \mathrm{ml} / \mathrm{min}$. The column was then washed with $10 \mathrm{ml}$ of distilled water. ADH was subsequently eluted with $25 \mathrm{ml}$ of $75 \%$ acid ethanol ( $\mathrm{pH} 2.0$, acidified by $\mathrm{HCl}$ ) as described by Moran et al. (1964). After addition of $0.1 \mathrm{ml}$ of $1 \%$ bovine albumin, the eluate was evaporated at 45 to $50^{\circ} \mathrm{C}$ with a rotatory evaporator under reduced pressure. The dried material was dissolved in $6 \mathrm{ml}$ of distilled water and reevaporated. The residue was finally dissolved in $0.5 \mathrm{ml}$ of $0.9 \%$ $\mathrm{NaCl}$ plus $0.03 \%$ acetic acid solution. For the bioassay, 0.2 to $0.3 \mathrm{ml}$ aliquot of the dissolved sample was injected intravenously into the rat, and synthetic arginine-vasopression (Sigma Chem. Co.) was used as the standard for this bioassay.

Water loaded ethanol-anesthetized rats were prepared as described in a previous paper (Kimura and Yokoyama 1973) and the urinary responses to the extract were recorded on a multichannel ink-writing recorder. Both urine flow rate and electrical conductivity of urine were recorded simultaneously as described in a previous paper (Kimura and Yokoyama 1973). The lowest dose which could be assayed by our present method, as examined with synthetic arginine-vasopressin, was $5 \mu \mathrm{U}$, in most rats, but it was possible to detect a dose less than $5 \mu \mathrm{U}$ in a small number of rats. The recovery rates of 100 and $1,000 \mu \mathrm{U}$ of synthetic arginine-vasopressin added to $10 \mathrm{ml}$ of human plasma were $89 \pm 3.9$ and $81 \pm$ $3.7 \%$ (mean \pm S.E.), respectively.

\section{Determination of osmolality of plasma and urine}

The osmolality of both plasma and urine was determined by measuring freezing point depression with an Advanced Instruments Osmometer.

\section{Statistical analysis}

The test statistics used to determine whether or not a significant change occured was the Student's t-test for paired observations.

\section{Results}

In normal subjects, the values of plasma $\mathrm{ADH}$ concentration, plasma and urine osmolality determined at $2 \mathrm{hr}$ after supper were $3.4 \pm 0.8 \mu \mathrm{U} / \mathrm{ml}$ (mean \pm S.E.), $285.7 \pm 2.8$ and $666 \pm 91 \mathrm{mOsm} / \mathrm{kg}$, respectively. $\mathrm{U} / \mathrm{P}$ osmolar ratio was $2.3 \pm 0.3$. On the other hand, in patients with chronic renal disease, the respective values determined at the same time and under the same experimental conditions were $3.3 \pm 0.9 \mu \mathrm{U} / \mathrm{ml}, 293.6 \pm 3.1$ and $359 \pm 14 \mathrm{mOsm} / \mathrm{kg}$. U/P osmolar ratio in 
these patients was $1.2 \pm 0.1$. Although there was no distinct difference in plasma $A D H$ level between both groups, urine osmolality and U/P osmolar ratio differed significantly $(p<0.05)$. These values for both normal subjects and patients were compared, as controls, with those obtained after dehydration and hydration tests.

After the overnight fasting (for $14 \mathrm{hr}$ ), urine osmolality in normal subjects markedly increased, the mean value being $917 \pm 32 \mathrm{mOsm} / \mathrm{kg}$. Plasma ADH level was $4.0 \pm 0.8 \mu \mathrm{U} / \mathrm{ml}$, the value being slightly higher than control level. However, the difference was not significant statistically. Plasma osmolality remained unchanged $(282.3 \pm 1.9 \mathrm{mOsm} / \mathrm{kg})$. $\mathrm{U} / \mathrm{P}$ osmolar ratio significantly increased to $3.3 \pm 0.1(\mathrm{p}<0.01)$. In patients with chronic renal diseases, plasma $\mathrm{ADH}$, plasma osmolality, urine osmolality and U/P osmolar ratio were $4.9 \pm 1.3 \mu \mathrm{U} / \mathrm{ml}, 296.3$ $\pm 3.2 \mathrm{mOsm} / \mathrm{kg}, 435 \pm 20 \mathrm{m0sm} / \mathrm{kg}$ and $1.5 \pm 0.1$, respectively. ADH concentration and plasma osmolality slightly increased as compared with respective control values but the differences were not significant statistically. Urine osmolality and $\mathrm{U} / \mathrm{P}$ osmolar ratio increased also in these patients, but the extent of increases was much smaller than that in normal group. The data obtained from individual experiments are listed in Table 2.

TABLE 2. Effect of the dehydration test on plasma ADH level and plasma and urine osmolality in normal subjects and patients with chronic renal diseases

\begin{tabular}{|c|c|c|c|c|c|c|c|c|}
\hline \multirow[b]{2}{*}{ Case } & \multicolumn{4}{|c|}{ Before dehydration } & \multicolumn{4}{|c|}{ After dehydration } \\
\hline & $\underset{(\mu \mathrm{U} / \mathrm{ml})}{\mathbf{P}_{\mathrm{ADH}}}$ & $\underset{(\mathrm{mOsm} / \mathrm{kg})}{\mathrm{P}_{\text {osm }}}$ & $\begin{array}{c}\mathrm{U}_{\mathrm{osm} \mathrm{m}} \\
(\mathrm{mOsm} / \mathrm{kg})\end{array}$ & $\mathrm{U} / \mathrm{P}$ & $\underset{(\mu \mathrm{U} / \mathrm{ml})}{\mathrm{P}_{\mathrm{ADH}}}$ & $\begin{array}{c}\text { Posm }_{\text {osm }} \\
(\mathrm{m} O \mathrm{~kg})\end{array}$ & $\begin{array}{c}\mathbf{P o s m}_{\text {os }} \\
(\mathrm{mOsm} / \mathrm{kg})\end{array}$ & $\mathrm{U} / \mathrm{P}$ \\
\hline O.N.* & 2.1 & 294 & 349 & 1.2 & 3.5 & 292 & 379 & 1.3 \\
\hline S.Y.* & 3.3 & 310 & 325 & 1.0 & 6.8 & 311 & 317 & 1.0 \\
\hline T.K.* & 2.9 & 286 & 370 & 1.3 & 3.3 & 285 & 498 & 1.8 \\
\hline T.A.* & 1.4 & 296 & 409 & 1.4 & 1.9 & 303 & 495 & 1.6 \\
\hline H.A.* & 2.3 & 291 & 311 & 1.0 & 1.7 & 298 & 578 & 1. 9 \\
\hline A.E. $\dagger$ & 2.1 & 288 & 402 & 1.4 & 4.9 & 288 & 422 & 1.4 \\
\hline T.H. + & 9.0 & 290 & 350 & 1,2 & 12,0 & 292 & 359 & 1.2 \\
\hline 'T.м. & 2.8 & 288 & 629 & 2.2 & 3.4 & 288 & 955 & 3.3 \\
\hline W.S. & 7.7 & 289 & 649 & 2.3 & 8.0 & 285 & 811 & 2.9 \\
\hline U.T. & 4.1 & 283 & 917 & 3.2 & 4.0 & 279 & 890 & 3.2 \\
\hline S.T. & 2.5 & 284 & 307 & 1.1 & 3.0 & 284 & 870 & 3.1 \\
\hline Y.T. & 4.1 & 296 & 798 & 2.7 & 4.7 & 285 & 1000 & 3.5 \\
\hline T.K. & 2.2 & 284 & 980 & 3.4 & 3.7 & 282 & 984 & 3.5 \\
\hline M.M. & 0.8 & 276 & 377 & 1.2 & 1.2 & 273 & 910 & 3.3 \\
\hline
\end{tabular}

* Chronic glomerulonephritis, † Polycystic kidney, $\ddagger$ Nephrocalcinosis.

Under the standard conditions after lunch, the values for plasma ADH concentration, plasma and urine osmolality, and $\mathrm{U} / \mathrm{P}$ osmolar ratio were $2.9 \pm 0.8$ $\mu \mathrm{U} / \mathrm{ml}, 288.5 \pm 3.4 \mathrm{mOsm} / \mathrm{kg}, 714 \pm 100 \mathrm{mOsm} / \mathrm{kg}$, and $2.5 \pm 0.3$, respectively, in normal subjects. After water load, both $A D H$ level and urine osmolality markedly decreased from $2.9 \pm 0.8$ to $0.3 \pm 0.2 \mu \mathrm{U} / \mathrm{ml}(\mathrm{p}<0.02)$ and from $714 \pm$ 100 to $81 \pm 21 \mathrm{mOsm} / \mathrm{kg}(\mathrm{p}<0.001)$ in normal subjects. Plasma osmolality also decreased to $271.1 \pm 7.7 \mathrm{msOm} / \mathrm{kg}(\mathrm{p}<0.1)$. U/P osmolar ratio significantly decreased to $0.3 \pm 0.1(\mathrm{p}<0.02)$. The data obtained from each individual experi- 
TABLE 3. Effect of water load on plasma ADH level and plasma and urine osmolality in normal subjects

\begin{tabular}{|c|c|c|c|c|c|c|c|c|}
\hline \multirow[b]{2}{*}{ Case } & \multicolumn{4}{|c|}{ Before water load } & \multicolumn{4}{|c|}{ After water load } \\
\hline & $\underset{(\mu \mathrm{U} / \mathrm{ml})}{\mathrm{P}_{\mathrm{ADH}}}$ & $\underset{(\mathrm{mOsm} / \mathrm{kg})}{\text { Posm }_{\text {osm }}}$ & $\begin{array}{c}\text { Uosm }_{\text {osm }} \\
(\mathrm{mOsm} / \mathrm{kg})\end{array}$ & $\mathrm{U} / \mathbf{P}$ & $\begin{array}{c}\mathrm{P}_{\mathrm{ADH}} \\
(\mu \mathrm{U} / \mathrm{ml})\end{array}$ & $\begin{array}{c}\mathrm{P}_{\text {osm }} \\
(\mathrm{mOsm} / \mathrm{kg})\end{array}$ & $\begin{array}{c}\mathrm{U}_{\mathrm{osm}} \\
(\mathrm{m} O \mathrm{sm} / \mathrm{kg})\end{array}$ & $\mathrm{U} / \mathrm{P}$ \\
\hline S.T. & 1.4 & 287 & 669 & 2.3 & 0 & 250 & 100 & 0.4 \\
\hline U.S. & 5.1 & 299 & 1200 & 4.0 & 0 & 280 & 116 & 0.4 \\
\hline F.U. & 2.1 & 291 & 606 & 2.1 & 0.85 & 285 & 43 & 0.2 \\
\hline M.L. & 4.6 & 290 & 725 & 2.5 & 0 & 279 & 72 & 0.3 \\
\hline S.A. & 1.4 & 279 & 465 & 1.7 & 0.7 & 280 & 169 & 0.6 \\
\hline K.T. & - & 285 & 621 & 2.2 & 0 & 253 & 32 & 0.1 \\
\hline
\end{tabular}

TABLE 4. Effect of the dehydration test on plasma ADH level and plasma and urine osmolality in patients with central diabetes insipidus

\begin{tabular}{|c|c|c|c|c|c|c|c|c|}
\hline \multirow[b]{2}{*}{ Case } & \multicolumn{4}{|c|}{ Before dehydration } & \multicolumn{4}{|c|}{ After dehydration } \\
\hline & $\underset{(\mu \mathrm{U} / \mathrm{ml})}{\mathrm{P}_{\mathrm{ADH}}}$ & $\underset{(\mathrm{mOsm} / \mathrm{kg})}{P_{\text {osm }}}$ & $\begin{array}{c}\mathrm{U}_{\mathrm{osm}} \\
(\mathrm{mOsm} / \mathrm{kg})\end{array}$ & $\mathrm{U} / \mathrm{P}$ & $\frac{\mathrm{P}_{\mathrm{ADH}}}{(\mu \mathrm{U} / \mathrm{ml})}$ & $\begin{array}{c}P_{\mathrm{osm}} \\
(\mathrm{mOsm} / \mathrm{kg})\end{array}$ & $\begin{array}{c}\mathrm{U}_{\mathrm{os} \mathrm{m}} \\
(\mathrm{mOsm} / \mathrm{kg})\end{array}$ & $\mathrm{U} / \mathrm{P}$ \\
\hline T.H.* & 0.7 & 284 & 90 & 0.8 & 0.4 & 289 & 116 & 0.4 \\
\hline O.W.* & 0 & 328 & 65 & 0.2 & 1.3 & 364 & 108 & 0.3 \\
\hline Y.S.* & - & - & - & - & 1.5 & 299 & 105 & 0.4 \\
\hline K.T.† & 1.1 & 284 & 207 & 0.7 & 0.9 & 290 & 219 & 0.7 \\
\hline N.H. $\dagger$ & 0.6 & 273 & 69 & 0.2 & 0.5 & 285 & 212 & 0.7 \\
\hline T.H. $\dagger$ & 0 & 295 & 93 & 0.3 & 0 & 302 & 199 & 0.7 \\
\hline S.T. $\dagger$ & 0.9 & 284 & 95 & 0.3 & 1.5 & 291 & 128 & 0.4 \\
\hline H.S. $\dagger$ & 0.5 & 285 & 140 & 0.5 & 1.0 & 290 & 260 & 0.9 \\
\hline I.S. & 0 & 283 & 92 & 0.3 & 0 & 290 & 107 & 0.5 \\
\hline K.Y.* & 0 & 281 & 235 & 0.8 & 1.8 & 300 & 441 & 1.4 \\
\hline
\end{tabular}

* Idiopathic, $†$ Pinealoma, $\ddagger$ Hand-Schüller-Christian disease.

ment are shown in Table 3. Water loading test was not performed in the patients. In patients with central diabetes insipidus, plasma $\mathrm{ADH}$ concentration, plasma and urine osmolality and U/P osmolar ratio in control period were $0.4 \pm 0.1 \mu \mathrm{U} / \mathrm{ml}$, $288.6 \pm 5.3 \mathrm{mOsm} / \mathrm{kg}, 120.7 \pm 20.3 \mathrm{mOsm} / \mathrm{kg}$ and $0.4 \pm 0.1$, respectively. After dehydration test, plasma $\mathrm{ADH}$ concentration, plasma and urine osmolality and $\mathrm{U} / \mathrm{P}$ osmolar ratio increased to $0.9 \pm 0.2 \mu \mathrm{U} / \mathrm{ml}(\mathrm{p}<0.05), 300 \pm 7.3 \mathrm{mOsm} / \mathrm{kg}$ $(\mathrm{p}<0.3), 190 \pm 32 \mathrm{mOsm} / \mathrm{kg}(\mathrm{p}<0.2)$ and $0.6 \pm 0.1(\mathrm{p}<0.2)$, respectively. The data obtained from individual experiments are shown in Table 4.

Mean values of plasma ADH concentration and U/P osmolar ratio of normal subjects, patients with chronic renal diseases and patients with central diabetes insipidus under three different experimental conditions were summarized in Fig. 1. In normal subjects, changes in plasma $\mathrm{ADH}$ concentration induced by changes in the state of hydration was in parallel with the changes in the U/P osmolar ratio. On the other hand, in patients with chronic renal diseases, significant change in $\mathrm{U} / \mathrm{P}$ osmolar ratio was not observed, though $\mathrm{ADH}$ concentration increased after the dehydration test. Moreover, U/P osmolar ratio was generally much lower even at a high $\mathrm{ADH}$ concentration than that of normal subjects. In normal 

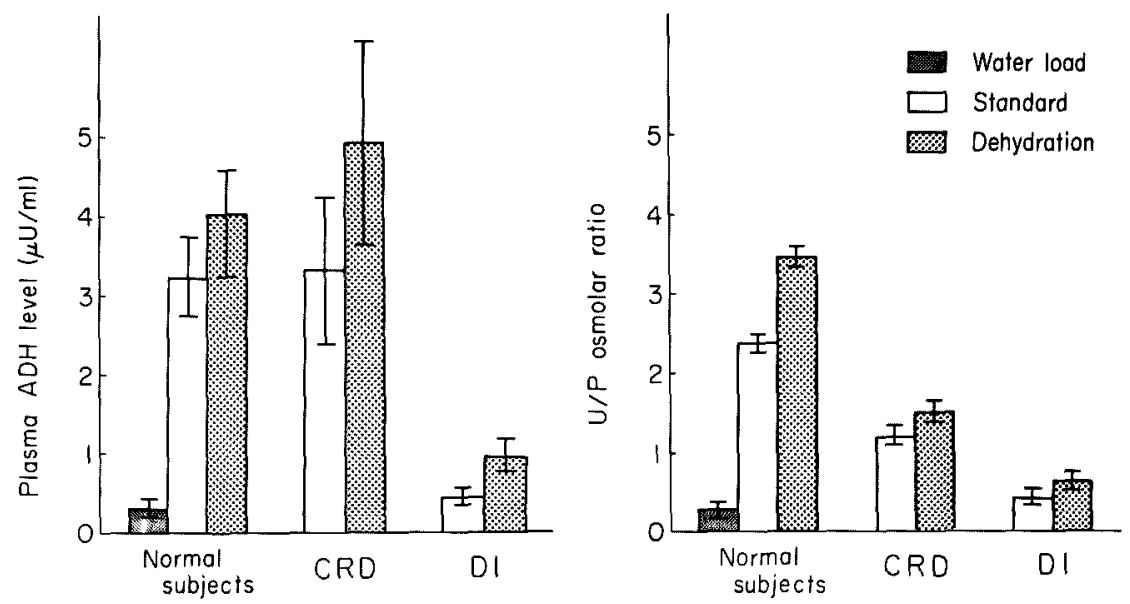

Fig. 1. Changes in plasma $A D H$ level and $U / P$ osmolar ratio under various hydrated states in normal subjects, patients with chronic renal diseases (CRD) and patients with central diabetes isipidus (DI). Each bar indicates mean \pm s.E.

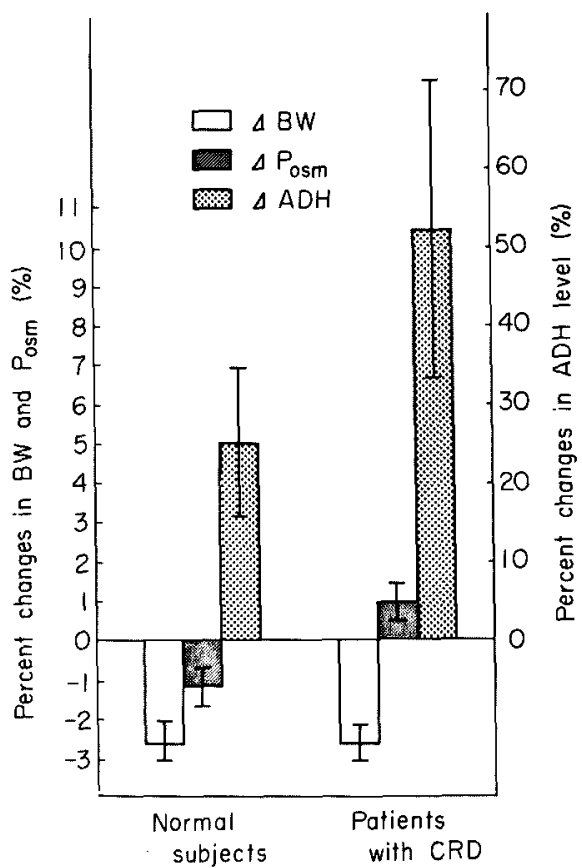

Fig. 2. Percent changes in body weight (BW), plasma osmolality $\left(\mathrm{P}_{\mathrm{osm}}\right)$ and plasma ADH level $(\mathrm{ADH})$ before and after $14 \mathrm{hr}$ overnight dehydration in normal subjects and patients with chronic renal disease (CRD). Each bar indicates mean \pm s.E. 
subjects, a well correlation between these was seen, but U/P osmolar ratio tended to saturate at the higher range of $\mathrm{ADH}$ concentration. In patients with central diabetes insipidus, both plasma $\mathrm{ADH}$ concentrations and $\mathrm{U} / \mathrm{P}$ osmolar ratios were very low regardless of the experimental states of hydration.

Fig. 2 shows percent changes in body weight, plasma $A D H$ level and plasma osmolality before and after the dehydration test in both groups. In normal subjects, the overnight fast and restriction of water intake resulted in a decrease of body weight by $2.6 \pm 0.5 \%$ and an increase in hematocrit by $3.2 \pm 0.5 \%$. Plasma ADH level increased by $25.1 \pm 9.4 \%$, while plasma osmolality decreased by $1.2 \pm 0.5 \%$. In contrast, in patients, plasma $\mathrm{ADH}$ concentration increased by $52.1 \pm 19 \%$ with a slight elevation of plasma osmolality by $0.9 \pm 0.5 \%$, though changes in body weight and hematocrit were similar to those in normal group. When the mean values of plasma $\mathrm{ADH}$ concentrations before and after the dehydration test were compared, statistically significant difference could not be detected, as described above, owing to a relatively large scattering of control values. However, when the percent increases in plasma ADH concentration in individual subjects were averaged, the average percent increase was significant statistically.

Relationship between plasma ADH level and plasma osmolality obtained from all subjects under various states of hydration is summarized in Fig. 3. No $\mathrm{ADH}$ activity was detected in plasma when plasma osmolality was less than 270 $\mathrm{mOsm} / \mathrm{kg}$. However, an abrupt increase in plasma ADH level was seen when plasma osmolality was more than $270 \mathrm{mOsm} / \mathrm{kg}$. Plasma ADH levels found in

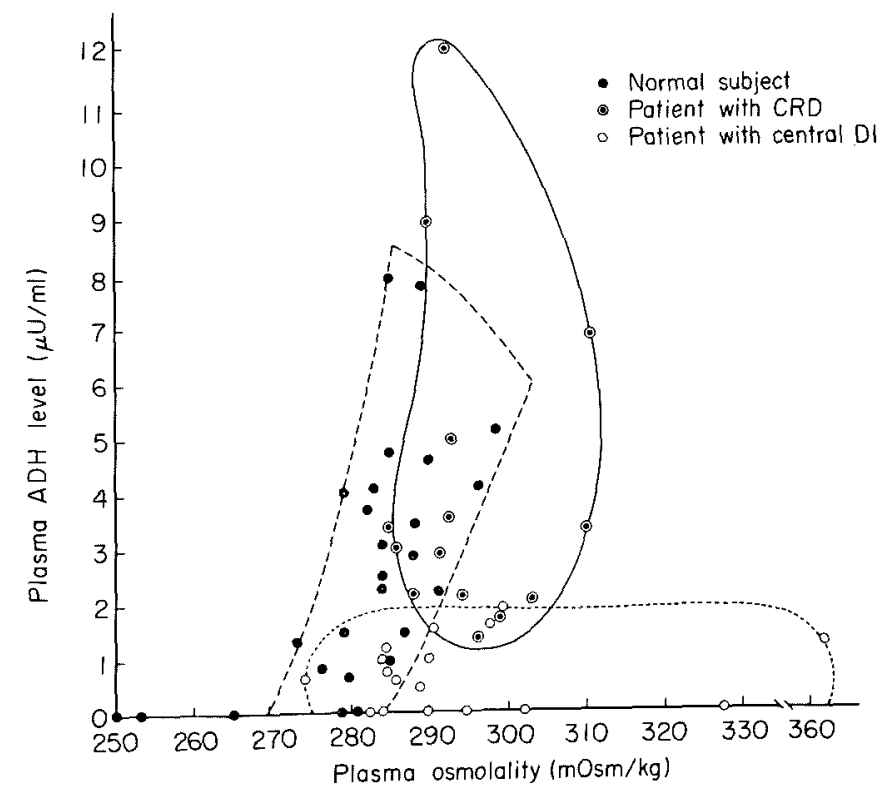

Fig. 3. Relationship between plasma ADH level and plasma osmolality in normal subjects, patients with chronic renal diseases and patients with central diabetes insipidus. 
normal subjects distributed in the area encircled by broken lines, whereas those from patients with chronic renal diseases were in another circle of continuous line. It was seen that the area of distribution of points shifted toward right from the normal distribution area. Some patients with chronic renal diseases had ADH levels more than $10 \mu \mathrm{U} / \mathrm{ml}$ even when plasma osmolality was around $290 \mathrm{mOsm} / \mathrm{kg}$, whereas some other patients with high blood pressure had very low $\mathrm{ADH}$ levels, less than $2 \mu \mathrm{U} / \mathrm{ml}$ even when plasma osmolality was around or more than 300 $\mathrm{mOsm} / \mathrm{kg}$. The ADH levels of patients with diabetes insipidus were mostly under $1.8 \mu \mathrm{U} / \mathrm{ml}$ in spite of a large scattering of plasma osmolality from 273 to 362 $\mathrm{mOsm} / \mathrm{kg}$ (encicled dotted line).

Fig. 4 shows the relationship between U/P osmolar ratio and plasma ADH concentration obtained from all subjects under various states of hydration. In normal subjects, the ratio increased as plasma $A D H$ level increased in the range of $\mathrm{ADH}$ concentration from 0 to $3 \mu \mathrm{U} / \mathrm{ml}$, but with higher $\mathrm{ADH}$ concentration, the ratio tended to saturate at the level of 3 to 4 . On the other hand, there was no clear correlation between $\mathrm{U} / \mathrm{P}$ osmolar ratio and $\mathrm{ADH}$ concentration in patients with renal diseases, and the ratios were between 1 and 2 over a wide range of plasma $\mathrm{ADH}$ concentration. In patients with control diabetes insipidus, plasma $\mathrm{ADH}$ levels remained under $1.5 \mu \mathrm{U} / \mathrm{ml}$ and $\mathrm{U} / \mathrm{P}$ osmolar ratios were less than 1 .

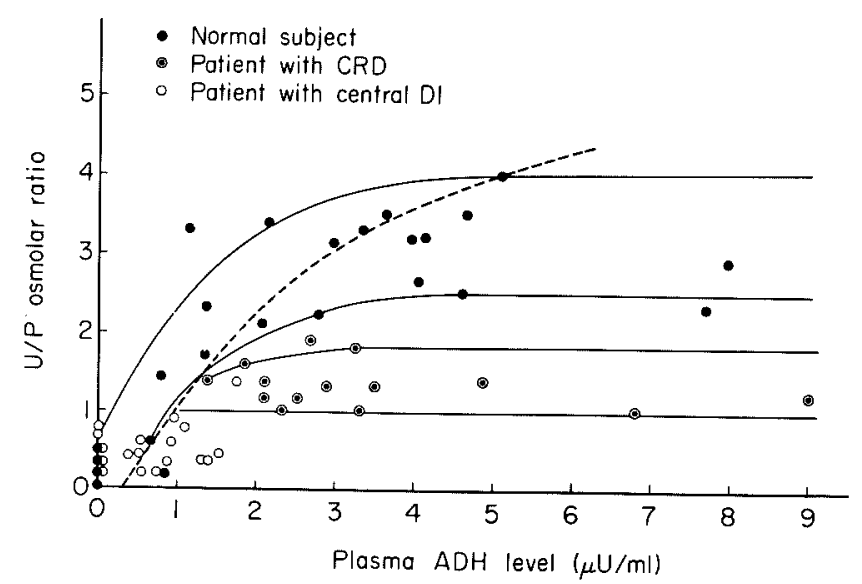

Fig. 4. Relationship between plasma $\mathrm{ADH}$ level and $\mathrm{U} / \mathrm{P}$ osmolar ratio in normal subjects, patients with chronic renal disease and patients with central diabetes insipidus. Dotted line is described by the equation $\left(\mathrm{Y}=-0.58+1.75 \mathrm{X}-0.17 \mathrm{X}^{2}\right)$.

\section{Discussion}

Plasma ADH concentration in normal subjects determined after overnight fast and restriction of water intake was $4.0 \pm 0.8 \mu \mathrm{U} / \mathrm{ml}$. Yoshida et al. (1963) and Czaczkes et al. (1964) reported that average plasma ADH concentrations after 16 hr deprivation of water were 5 to $8 \mu \mathrm{U} / \mathrm{ml}$. On the other hand, Share et al. (1972) reported a value of $2.1 \mu \mathrm{U} / \mathrm{ml}$, for normal subjects after a similar dehydration 
period, the value being much lower then those reported by above authors. Since the period of restriction of water intake was similar in these studies, the differences in observed values could be ascribed to differences either the methods of determining $\mathrm{ADH}$ concentration or the state of the subjects before the dehydration test.

Plasma $\mathrm{ADH}$ concentration $2 \mathrm{hr}$ after the breakfast has been reported by Yoshida et al. (1963) to be $1.9 \pm 0.3 \mu \mathrm{U} / \mathrm{ml}$. The values for the conditions $2 \mathrm{hr}$ after lunch and supper measured in the present study were $2.9 \pm 0.8$, and $3.3 \pm$ $0.6 \mu \mathrm{U} / \mathrm{ml}$, respectively. Such differences in $\mathrm{ADH}$ concentration could, at least in part, be accounted for by diurnal variation of $\mathrm{ADH}$ level in normal men.

Several authors have attempted to estimate plasma osmotic threshold for ADH release. Aubry et al. (1965) and Moses et al. (1967) reported values of 289 \pm 2.5 and $285 \pm 2.9 \mathrm{mOsm} / \mathrm{kg}$, respectively, for the threshold osmolality in man. These values, however were derived from indirect studies. For example, Aubry et al. (1965) measured plasma osmolality at the time when free water clearance fell significantly during hypertonic saline infusion to water diuretic man. Our data on the relationship between plasma osmolality and plasma $\mathrm{ADH}$ concentration reveal that $\mathrm{ADH}$ concentration abruptly increases when plasma osmolality reaches to $270 \mathrm{mOsm} / \mathrm{kg}$. However, when plasma $\mathrm{ADH}$ concentration was less than 1 $\mu \mathrm{U} / \mathrm{ml}, \mathrm{U} / \mathrm{P}$ osmolar ratio remained less than 1. Accordingly, plasma osmolality which effectively induces urinary concentration is considered to be a little higher than the true plasma threshold. The present results show such plasma osmolality, that is the apparent threshold, would be between 275 and $280 \mathrm{mOsm} / \mathrm{kg}$. These values are still slightly lower than those reported by Aubry et al. (1965) and Moses et al. (1967).

O'Conner (1962) estimated plasma osmolality in water diuretic dog which effectively caused a decrease in urine flow on hypertonic saline infusion and correlated this to calculated plasma ADH concentration after an administration of exogenous $\mathrm{ADH}$ which caused similar urinary changes. He showed that there was a linear relationship between the plasma osmolality and calculated ADH levels. In the present study, a strict linear relationship could not be observed between plasma ADH concentration and plasma osmolality, and a relatively great scattering was seen in this relationship. It is supposed that there may be many uncontrollable factors affecting this relationship. As it is known that the plasma volume has a great effect on $\mathrm{ADH}$ release, one of the important factors responsible for such a scattering may be the differences in plasma volume among subjects investigated.

In both normal subjects and patients with renal disease, a significant decrease in body weight and an increase in hematocrit were found after $14 \mathrm{hr}$ overnight fast. These changes could be explained by body water depletion. Nevertheless, plasma osmolality remained almost unchanged in normal subjects under these conditions, whereas it increased slightly in patients. On the other hand, plasma ADH concentration increased in both groups under these conditions, $25 \%$ in the former 
group and $52 \%$ in the latter group, when compared with control samples for this series of experiment for each of individuals.

It is generally considered that the depletion of body water results in an elevation of plasma osmolality, which, in turn, brings about an increase in plasma ADH concentration. In normal subjects, water reabsorption by renal tubules is enhanced by increased plasma $\mathrm{ADH}$ concentration which produces hypertonic urine. Unchanged plasma osmolality observed in normal subjects can be accounted for by effective excretion of solute over water by the kidney. As body weight decreaes under these conditions, total body content of sodium should have also decreased. On the other hand, in patients with chronic renal disease, incomplete renal reabsorption of water and insufficient regulation of balance of solutes and water excretion may lead to a significant increase in plasma osmolality. If plasma osmolality is the sole stimulant for ADH release, it is difficult to explain the increased plasma ADH concentration in normal subjects with unchanged plasma osmolality under dehydrated conditions. As body weight and hematocrit increase significantly, it seems likely that the shrinkage of plasma volume may be responsible for the maintenance of a high level of ADH. Such an interpretation may be supported by experimental results of Segar and Moore (1968) and Rogge et al. (1967). They showed that in man alterations in the distribution of blood in the body greatly affected ADH release. In animals, it has been shown that a decrease in blood volume by hemorrhage could also increase the release of $\mathrm{ADH}$ (Weinstein et al. 1960; Share 1967; Johnson et al. 1969). These facts indicate that volume receptor mechanism play an important role in $\mathrm{ADH}$ release. Therefore, it may be interpreted that the increased ADH concentration without an increase in plasma osmolality may be due to, at least in part, the stimulation of the volume receptor mechanism. A greater increase in plasma $\mathrm{ADH}$ in patients than in normal subjects may be due to an additive effect of both an increse in plasma osmolality and a decrease in plasma volume.

In some patients with pituitary diabetes insipidus, the plasma ADH concentrations were measurable, but it was very low or subnormal even when their plasma osmolality was higher than the normal range. It was found that the ADH levels tended to increase, to some extent after the dehydration test, and urine osmolality was also tended to increase slightly. These findings indicate that many patients with pituitary diabetes insipidus retain some capacity to secrete $\mathrm{ADH}$ in response to an increase in plasma osmolality, but the amount of secretion is too small to bring about the normal urinary response. On the other hand, some patients had an incresed urine osmolality despite of no remarkable changes in plasma $\mathrm{ADH}$ after dehydration test. This increase might be, at least in part, brought about by a reduction of renal glomerular filtration rate during dehydration, as suggested by Berliner and Davidson (1957).

Segar et al. (1968) studied the relationship between plasma ADH level and osmolality of both plasma and urine in man, and they found that plasma ADH was $1.65 \pm 0.63 \mu \mathrm{U} / \mathrm{ml}$ when $\mathrm{U} / \mathrm{P}$ osmolar ratio ranged from 1.95 to 3.75 . Moore 
(1971) presented a formula describing the relationship between plasma $A D H$ and $\mathrm{U} / \mathrm{P}$ asmolar ratio, as $\mathrm{Y}=0.11+1.35 \mathrm{X}-0.12 \mathrm{X}^{2}$, where $\mathrm{Y}$ is $\mathrm{U} / \mathrm{P}$ osmolar ratio and $\mathrm{X}$ is plasma $\mathrm{ADH}$ level. We tried to derive a similar equation, and obtained the following equation; $\mathrm{Y}=-0.58+1.75 \mathrm{X}-0.17 \mathrm{X}^{2}$. The latter is quite similar to the former.

\section{Addendum}

During the preparation of this manuscript, Robertson et al. (1973) published a paper dealing with plasma ADH levels of normal subjects and patients with diabetes insipidus. They employed a newly developed radioimmunoassay techniques. Their data on the relationship between plasma $\mathrm{ADH}$ level and plasma osmolality and that between plasma ADH level and U/P osmolar ratio are surprisingly similar to those obtained in the present study though the assay techniques are principally different.

\section{References}

1) Aubry, R.H., Nankin, H.R., Moses, A.M. \& Streeten, D.H.P. (1965) Measurement of the osmotic threshold for vasopressin release in human subjects, and its modification by cortisol. J. clin. Endocr., 25, 1481-1492.

2) Berliner, R.W. \& Davidson, D.G. (1957) Production of hypertonic urine in the absence of pituitary antidiuretic hormone. J. clin. Invest., 36, 1416-1427.

3) Claybaugh, J.R. \& Share, L. (1972) Role of the renin-angiotensin system in the vasopressin response to hemorrhage. Endocrinology, 90, 453-460.

4) Czaczkes, J.W., Kleeman, C.R. \& Koenig, M. (1964) Physiologic studies of antidiuretic hormone by its direct measurement in human plasma. J. clin. Invest., 43, 1625-1640.

5) Johnson, J.A., Moore, W.W. \& Segar, W.E. (1969) Small changes in left atrial pressure and plasma antidiuretic hormone titers in dogs. Amer. J. Physiol., 217, 210214.

6) Kimura, T. \& Yokoyama, R. (1973) A comparison of patterns of changes in urine flow and urine electrical conductivity induced by exsogenous ADH in hydrated rats. Tohoku J. exp. Med., 109, 281-296.

7) Moore, W.W. (1971) Antidiuretic hormone levels in normal subjects. Fed. Proc. 30, 1387-1394.

8) Moran, W.H., Jr., Miltenberger, F.W., Shuayb, W.A. \& Zimmermann, B. (1964) The relationship of antidiuretic hormone secretion to surgical stress. Surgery, 56, 99-108.

9) Moses, A.M., Miller, M. \& Streeten, D.H.P. (1967) Quantitative influence of blood volume expansion on the osmotic threshold for vasopressin release. J. clin. Endocr., $27,655-662$.

10) O'Conner, W.J. (1962) Release of antidiuretic hormone from the neurohypophysis. In: Renal Function. ed. 1, Edward Arnold (Publishers) Ltd., London, pp. 50-63.

11) Robertson, G.L., Mahr, E.A., Athar, S. \& Sinha, T. (1973) Development and clinical application of a new method for the radioimmunoassay of arginine vasopressin in human plasma. J. clin. Invest., 52, 2340-2352.

12) Rogge, J.D., Moore, W.W., Segar, W.E. \& Fasola, A.F. (1967) Effect of +Gz and $+\mathrm{Gx}$ acceleration on peripheral venous $\mathrm{ADH}$ levels in humans. $J$. appl. physiol., 23, $870-874$.

13) Segar, W.E. \& Moore, W.W. (1968) The regulation of antidiuretic hormone release in man. 1. Effects of change in position and ambient temparature on blood ADH levels. J. clin. invest., 47, 2143-2151.

14) Share, L. (1967) Role of peripheral receptors in the increased release of vasopressin in response to hemorrhage. Endocrinology, 81, 1140-1146. 
15) Share, L., Claybaugh, J.R., Hatch, F.E., Jr., Johnson., J.G., Lee, S., Muirhead, E.E. \& Shaw, P. (1972) Effects of change in posture and of sodium depletion on plasma levels of vasopressin and renin in normal human subjects. J. clin. Endocr., 35, 171174.

16) Yoshida, S., Motohashi, K., Ibayashi, H. \& Okinaka, S. (1963) Method for the assay of antidiuretic hormone in plasma with a note on the antidiuretic titer of human plasma. J. Lab. clin. Med., 62, 279-285.

17) Weinstein, H., Berne, R.M. \& Sachs, H. (1960) Vasopressin in blood: effect of hemmorrhage. Endocrinology, 66, 712-718. 